Огляди літератури, оригінальні дослідження, погляд на проблему, випадок з практики, короткі повідомлення UDC 616.316.1-091.8-02:616.24:616.12-008.331.1-089]-092.9

DOI 10.11603/1811-2471.2020.v.i4.11752

\title{
MORPHOMETRIC STUDY OF ARTERIES OF THE LOWER JAW REORGANIZATION ASPECTS IN THE SIMULATED POST-RESECTION ARTERIAL PULMONARY HYPERTENSION
}

\author{
๑L. Ya. Posolenyk
}

\section{Horbachevsky Ternopil National Medical University}

SUMMARY. The salivary glands are a special group of secretory organs that play a significant role in dental health of the population, as well as one of the vital functions of the whole human body. With the development of modern medical science, clinicians have often diagnosed salivary gland pathology. One of the most important problems of these pathologies is the study of direct and reverse effects of organs on each other, the principles of their correlations and methods of morphological expression. In recent decades, there has also been an increase of pulmonary lesions, which are accompanied by hypertension in the small circulation and lead to the development of pulmonary heart disease and its decompensation. There are isolated studies on the features of the involvement of the mandibular gland in the pathological process, and only some works reflect the structural changes of the submandibular gland in hemodynamic disorders.

The aim of the work - to study morphometric aspects of mandibular arteries reorganization in simulated post-resection arterial pulmonary hypertension.

Material and Methods. The arteries of medium (51-125) $\mu \mathrm{m}$ and small (26-50) $\mu \mathrm{m}$ calibers [16] of the mandibular salivary gland of 27 Vietnamese pigs, which were divided into 3 groups, were studied by a complex of histological and morphometric methods. Group 1 included 9 intact animals aged 6.5-7 months, group 2 - 12 pigs of the same age with post-resection pulmonary hypertension and compensated pulmonary heart, group 3-6 animals 6.5-7 months with pulmonary hypertension and decompensated pulmonary heart.

Results and Discussion. Hypertension (one-month term) in the small circle of blood circulation, which occurred after right-sided pulmonectomy led to the development of pulmonary heart and venous stasis in the organs of the large circle of blood circulation, including in the mandibular gland. At arterial hypertension in a small circle of blood circulation essential structural reorganization of arteries of a mandibular gland is revealed. Although morphological changes were found in the arteries of small caliber of the studied organ and in the decompensation of the pulmonary heart.

Conclusions. Our morphological study provided comprehensive information on the features of remodeling of the mandibular arteries in postresection arterial pulmonary hypertension. Prolonged pulmonary hypertension leads to structural rearrangement of the arteries of the middle and small caliber of the mandible, which is characterized by thickening of the membrane, narrowing their lumen and endothelial cells damage, impaired blood supply and hypoxia in the body. The biggest changes are in the arteries of the small caliber of the mandibular gland and in the decompensation of the pulmonary heart in 6.5-7 month old male pigs of the Vietnamese breed.

KEY WORDS: mandibular gland; arteries; remodeling; pulmonary hypertension.

Introduction. Salivary glands are a special group of secretory organs that play a significant role in dental health of population, as well as the vital functions of the whole human body [1-3]. Human body is exposed to various stressors throughout life. Analysis of the main quantitative and qualitative indicators of salivation revealed that salivary glands are highly sensitive to various stimuli $[4,5]$. The quantity and high quality of saliva affect the coagulation-fibrinolytic and vascular-platelet links of hemostasis. The quantity and quality of saliva depend on the course of inflammatory processes in the mucous membrane of the oral cavity, salivary glands and even in the soft tissues of the maxillofacial area. When salivation, its qualitative and quantitative composition are disturbed, the reparative processes of the mucous membrane deteriorate and the regulation of erythropoiesis changes. Gland dysfunction can be complicated by xerostomia. Also, it can worsen the course of many somatic pathologies. Problems of salivary gland diseases, their etiology and patho- genesis, participation in digestive processes, dysfunction due to pathology of the same digestive, endocrine, nervous, respiratory, excretory systems, taking various drugs, viral infections and the consequences of the same dysfunctions over the past decade are widespread studied, experimentally and clinically [6-8]. With the development of modern medical science, clinicians began to frequently diagnose pathology of salivary glands. A large number of etiological factors in the development of inflammatory diseases of salivary glands and their dysfunctions are described in literature. The study of direct and reverse effects of organs on each other, the principles of their correlations and methods of morphological expression is among the important problems of these pathologies [9].

We point out that there has also been an increase in cases of lung damage in recent decades, which are accompanied by hypertension in the small circulation and lead to the development of pulmonary heart disease and its decompensation [10]. The development 
Огляди літератури, оригінальні дослідження, поглядн на of these complications is accompanied by venous congestion in the circulatory system, dystrophic, necrobiotic, infiltrative and sclerotic changes. It should be noted that there are isolated studies on the peculiarities of the involvement of the submandibular gland in the pathological process, and only some works reflect the structural changes of the submandibular gland in hemodynamic disorders [11].

The general conclusion from the analysis of the given works follows that search and development of new morphological methods of research of a submandibular gland, studying its morphogenesis at hypertension in a small circle of blood circulation is an actual problem which demands in-depth comprehensive study of the specified organ and innovative realization of the new medical and technological decisions, directed at increasing the effectiveness of corrective measures.

The aim of the study - morphometric study of reorganization aspects of submandibular arteries in simulated postresection arterial pulmonary hypertension.

Material and Methods. The work was carried out at the Department of Operative Surgery and Clinical Anatomy of I. Horbachevsky Ternopil National Medical University of the Ministry of Health of Ukraine.

The arteries of medium (51-125) $\mu \mathrm{m}$ and small (26-50) $\mu \mathrm{m}$ calibers of submandibular salivary gland of 27 Vietnamese pigs, which were divided into 3 groups, were examined with a complex of histological and morphometric methods. Group 1 included 9 intact animals aged 6.5-7 months, group $2-12$ pigs of the same age with post-resection pulmonary hypertension and compensated pulmonary heart disease, group $3-6$ animals aged 6.5-7 months with pulmonary hypertension and decompensated pulmonary heart disease. The animals were in normal conditions and in the diet of vivarium. Pulmonary arterial hypertension was modelled by right-sided pneumonectomy, роблему, випадок з практики, короткі повідомлення which resulted in pulmonary artery hypertension, hyperfunction and hypertrophy of the right ventricle (pulmonary heart disease) [12].

Euthanasia of experimental animals was performed one month after the start of the experiment by bloodletting under thiopental anesthesia. Pieces were cut from the submandibular gland, which were fixed in $10.0 \%$ neutral formalin solution and after passing through ethyl alcohols of increasing concentration was placed in paraffin. Microtome sections were stained with hematoxylin and eosin, according to van Gizon, Weigert. It was determined morphometrically the outer and inner diameters of the arteries of the submandibular gland, the thickness of medium, the Wogenworts index (the ratio of the area of the artery to its lumen), the relative volume of the affected endothelial cells. Quantitative indicators were processed statistically. The difference between the comparative values was determined by Student's t-test. All manipulations with experimental pigs were carried out in accordance with the rules laid down by the European Commission for the supervision of laboratory and other experiments involving experimental animals of different species.

Results and Discussion. One-month hypertension in the small circle of blood circulation, which occurred after right-sided pneumonectomy, led to the development of pulmonary heart disease and venous congestion in the organs of the great circle of blood circulation, including the submandibular gland. A set of morphological methods showed that postresection arterial pulmonary hypertension leads to a pronounced remodelling of the structures of submandibular gland in Vietnamese male pigs.

Morphometric measurements of arteries of medium and small calibers of the submandibular gland of 6.5-7 month old experimental animals with postresection arterial pulmonary hypertension are presented in Table 1.

Table 1. Morphometric characteristics of the arteries of the submandibular gland $(M \pm m)$

\begin{tabular}{|l|c|c|c|}
\hline \multirow{2}{*}{ Parameter } & \multicolumn{2}{c|}{ Observation group } \\
\cline { 2 - 4 } & \multicolumn{1}{|c|}{ I } & II \\
\hline \multicolumn{1}{|c|}{1} & 2 & 3 & 4 \\
\hline Outer diameter, $\mu \mathrm{m}$ & $76.40 \pm 1.92$ & $78.90 \pm 1.8$ & $79.30 \pm 1.83$ \\
\hline Inner diameter, $\mu \mathrm{m}$ & $28.20 \pm 0.60$ & $23.60 \pm 0.57^{* *}$ & $22.40 \pm 0.42^{* * *}$ \\
\hline Thickness of medium, $\mu \mathrm{m}$ & $14.10 \pm 0.30$ & $16.30 \pm 0.27^{* *}$ & $17.10 \pm 0.33^{* * *}$ \\
\hline Wogenworts index, \% & $733.90 \pm 18.30^{* *}$ & $1117.7 \pm 18.6^{* * *}$ & $1253.2 \pm 19.2^{* * *}$ \\
\hline $\begin{array}{l}\text { Relative volumes of damaged } \\
\text { endothelial cells, \% }\end{array}$ & $2.60 \pm 0.06^{* *}$ & $10.6 \pm 0.15^{* * *}$ & $18.50 \pm 0.15^{* * *}$ \\
\hline \multicolumn{2}{|c|}{ Small caliber arteries } \\
\hline Outer diameter, $\mu \mathrm{m}$ & $32.60 \pm 0.90$ & $36.50 \pm 0.75$ & $37.10 \pm 0.87$ \\
\hline Inner diameter, $\mu \mathrm{m}$ & $13.70 \pm 0.33^{* *}$ & $10.70 \pm 0.15^{* * *}$ & $10.30 \pm 0.24^{* * *}$ \\
\hline Thickness of medium, $\mu \mathrm{m}$ & $6.90 \pm 0.18^{*}$ & $8.60 \pm 0.18^{* * *}$ & $8.80 \pm 0.21^{* * *}$ \\
\hline
\end{tabular}


Огляди літератури, оригінальні дослідження, погляд на проблему, випадок з практики, короткі повідомлення

Continuation of Table 1

\begin{tabular}{|l|c|c|c|}
\hline \multicolumn{1}{|c|}{1} & 2 & 3 & 4 \\
\hline Wogenworts index, \% & $566.30 \pm 11.40^{* * *}$ & $1163.6 \pm 15.3^{* * *}$ & $1296.0 \pm 13.2^{* * *}$ \\
\hline $\begin{array}{l}\text { Relative volumes of damaged } \\
\text { endothelial cells, \% }\end{array}$ & $4.10 \pm 0.12^{* * *}$ & $36.50 \pm 0.45^{* * *}$ & $41.50 \pm 0.48^{* * *}$ \\
\hline
\end{tabular}

Note. * $-p<0.05 ; * *-p 0.01 ; * * *-p 0.001$ compared with group 1 of observations.

Analysis of these morphometric parameters of arteries of medium caliber 6.5-7 months Vietnamese pigs revealed that they changed significantly while having postresection arterial pulmonary hypertension. Thus, the outer diameter of the studied vessels in simulated pathology and compensated pulmonary heart disease was increased by $3.27 \%$ and by $3.8 \%$ in decompensated hypertrophied heart. The thickness of the medium of the arteries of the middle caliber of the submandibular gland in postresection arterial pulmonary hypertension and compensated pulmonary heart disease increased from $(14.10 \pm 0.30)$ to $(16.30 \pm$ $0.27) \mu \mathrm{m}$, i. e. by $15.6 \%$. These morphometric parameters differed significantly statistically $(p<0,01)$. The investigated morphometric indicator was increased by $21.3 \%$ during decompensation of the hypertrophied heart in comparison with the similar control size. The Wogenworts index of these arteries in the simulated experimental conditions with a high degree of reliability $(p<0.001)$ was increased 1.52 and 1.71 times, respectively. The inner diameter of the arteries of the middle caliber of the submandibular gland after rightsided pneumonectomy and compensated pulmonary heart disease was decreased from $(28.20 \pm 0.60)$ to $(23.60 \pm 0.57) \mu \mathrm{m}$. A statistically significant $(p<0.01)$ difference was found between the given morphometric parameters. The last morphometric parameter was lower than the previous one by $16.3 \%$. In postresection arterial pulmonary hypertension and decompensated pulmonary heart disease, the detected decrease was $20.5 \%$. In the simulated experiment, the relative volume of damaged endothelial cells of the arteries of the middle caliber of the submandibular gland increased markedly $(p<0.001)$. Thus, in postresection arterial pulmonary hypertension and compensated pulmonary heart, this morphometric parameter increased 4.07 times, and in pulmonary heart failure 7.1 times.

It was found that under the simulated pathological conditions the morphometric parameters of small caliber arteries changed significantly. The outer diameter of the studied vessels in the conditions of compensated pulmonary heart disease was increased by $11.9 \%$, and by $13.8 \%$ with decompensation of the pulmonary heart disease. The inner diameter of the arteries of the small caliber of submandibular gland after right-sided pneumonectomy and compensated pulmonary heart disease decreased from $(10.70 \pm 0.15)$ to $(10.30 \pm 0.24) \mu \mathrm{m}$, respectively by $21.9 \%$ and $24.8 \%$ relatively to the control group of the studied animals. A statistically significant $(p<0.001)$ difference was found between these morphometric parameters. The thickness of medium of small caliber arteries of submandibular gland in group 2 of observations (postresection arterial pulmonary hypertension and compensated pulmonary heart disease) decreased from $(6.90 \pm 0.18)$ to $(8.60 \pm 0.21) \mu \mathrm{m}$, e. i. by $24.6 \%$. It should be noted that the above morphometric parameters were statistically significantly different $(p<0.001)$. During pulmonary heart disease decompensation the established increase made $27.5 \%$. The Wogenworts index under these experimental conditions increased statistically significantly $(p<0.001)$ by 2.05 and 2.3 times, respectively. The relative volumes of damaged endotheliocytes of the small caliber arteries of the submandibular gland in postresection arterial pulmonary hypertension changed significantly. Thus, in group 2 of observations the specified morphometric parameter was equal to $(36.50 \pm 0.45) \%$ and $(41.50 \pm 0.48) \%$ in group 3. These indicators exceeded the same control value by 8.9 and 10.1 times, respectively.

It was revealed a significant structural rearrangement of the arteries of the submandibular gland with arterial hypertension in the small circle of blood circulation, which was characterized by an increase in the outer diameter of these vessels, thickening of their wall, narrowing of the lumen, damaging endothelial cells.

Quantitative morphological analysis proved that postresection arterial pulmonary hypertension leads to pronounced remodeling of the arteries of the submandibular gland. More pronounced morphological changes were found in the small caliber arteries of the studied organ. The dominant structural rearrangement of the small caliber arteries of the submandibular gland in the simulated pathology can be explained by the fact that they play a major role in the blood supply to organs and the regulation of their blood supply. These vessels are more loaded in the physiological conditions of the organism compared to the arteries of larger calibers and in the event of a pathological condition, they are damaged first and to a greater extent compared to the arteries of larger calibers.

It should be noted that the degree of venous stasis depended on the peculiarities of hemodynamics, i. e. venous plethora was most pronounced in pulmonary heart disease decompensation. It is known that prolonged venous stasis in the studied organ led to 
Огляди літератури, оригінальні дослідження, погляд на poxia).

Conclusions. A comprehensive morphological study provided comprehensive information on the features of remodelling of the submandibular arteries in postresection arterial pulmonary hypertension. Prolonged pulmonary hypertension leads to a pronounced structural rearrangement of the middle and small caliber arteries of the submandibular gland, which is characterized by thickening of the wall, narrowing of their lumen and damage to endo- проблему, випадок з практики, короткі повідомлення thelial cells, impaired blood supply and hypoxia in the organ. The most pronounced changes are the small caliber arteries of the submandibular gland and during the decompensated pulmonary heart disease in 6.5-7-month-old Vietnamese male pigs.

Prospects for further research. A long-term study of the submandibular gland in the development of cardiovascular pathology, which is necessary in the diagnosis, correction, treatment and development of measures to prevent salivary gland lesions, should be considered promising.

\section{LIST OF LITERATURE}

1. Рибалов О. В. Структура запальних захворювань слинних залоз / О. В. Рибалов, В.М.Гаврильєв // Український стоматологічний альманах. - 2007. - № 4. C. 15-18.

2. Табачнюк Н. В. Оцінка інформативності методів діагностики при дослідженні морфогенезу піднижньощелепної слинної залози / Н. В. Табачнюк, І. Ю. Олійник // Клінічна та експериментальна патологія. -2010. T. IX, № 3 (33). - C. 148-152.

3. Gilon Y. Systemic pathology and the salivary glands / Y. Gilon // Rev. Blge. Med. Dent. - 2006. - Vol. 61, No. 3. - P. 154-160.

4. Непорада К. С. Метаболічні зміни в слинних залозах за пептичної виразки шлунка та їх корекція L-аргініном / K. С. Непорада // Фізіол. журн. - 2003. - T. 49, № 6. - C. 70-74.

5. Тарасенко Л. М. Слюнные железы и слюна как чувствительные объекты исследования стрессоустойчивости организма (Обзор собственных исследований, к 100-летию открытия условного рефлекса) / Л. М. Тарасенко, К. С. Непорада, Т. А. Петрушанко // Український стоматологічний альманах. -2004. - № 5-6.C. 31-34.

6. Еричев И. В. Латерализированность саливации у людей с интактнымы зубными рядами / И. В. Еричев,
Г. Ф. Коротько, Л. А. Скорикова // Аллергология и иммунология. - 2004. - Т. 5, № 3. - С. 520.

7. Possible etiology of calculi formation in salivary glands: biophysical analysis of calculus / M. Mimura, N. Tanaka, S. Ichinose [et al.] // Med. Mol. Morphol. - 2005. - Vol. 38, No. 3. - P. 189-195.

8. Temporal reduction in size of salivary acinus in rats induced by theophylline / S. Kajikawa, A. Takeuchi, A. Nii [et al.] // Toxicol. Pathol. - 2005. - Vol. 33, No. 2. - P. 218-224.

9. Gilon Y. Systemic pathology and the salivary glands / Y. Gilon // Revue Beige de Medecine Dentaire. 2006. - Vol. 61, No. 3. - P. 154-160.

10. Гнатюк М. С. Особливості структурної перебудови кардіоміоцитів передсердь в умовах пострезекційної легеневої гіпертензії / М. С. Гнатюк, Л. В. Татарчук, О. Б. Слабий // Вісник проблем біології і медицини. 2019. - Вип. 3. - С. 283-286.

11. Frasch $\mathrm{H}$. Endothelin-1 is elevated in monocrotalin pulmonary hypertension / H. Frasch, C. Marshall, B. Marshall / Am. J. Physiol. 2002. - Vol. 300, No. 2. - P. 442-449.

12. Гнатюк М. С. Особливості ремоделювання камер серця з різними типами кровопостачання при артеріальній гіпертензії в малому колі кровообігу / М. С. Гнатюк, Л. В. Татарчук, О. Б Слабий // Вісник проблем біології і медицини. - 2016. - Вип. 3, №3. - С. 4145.

\section{REFERENCES}

1. Ribalov, O.V., \& Gavriljev, V.M. (2007). Struktura zapalnykh zakhvoriuvan slynnykh zaloz [The structure of inflammatory diseases of the salivary glands]. Ukrainskyi stomatolohichnyi almanakh - Ukrainian Dental Almanac, 4, 15-18 [in Ukrainian].

2. Tabachniuk, N.V., \& Olijnyk, I.Yu. (2010). Otsinka informatyvnosti metodiv diahnostyky pry doslidzhenni morfohenezu pidnyzhnoshchelepnoi slynnoi zalozy [Evaluation of the informativeness of diagnostic methods in the study of morphogenesis of the mandibular salivary gland]. Klinichna ta eksperymentalna patolohiia - Clinical and Experimental Pathology, 9, 3 (33), 148-152 [in Ukrainian].

3. Gilon, Y., (2006). Systemic pathology and the salivary glands. Rev. Blge. Med. Dent., 61 (3), 154-160.
4. Neporada, K.S. (2003). Metabolichni zminy v slynnykh zalozakh za peptychnoi vyrazky shlunka ta yikh korektsiia L-arhininom [Metabolic changes in the salivary glands in peptic ulcer and their correction with L-arginine]. Fiziol. Zhurn. - Physiological Journal, 49 (6), 70-74 [in Ukrainian].

5. Tarasenko, L.M., Neporada, K.S., \& Petrushanko, T.A. (2004). Slyunnyye zhelezy i slyuna kak chuvstvitelnyye obyekty issledovaniya stressoustoychivosti organizma (Obzor sobstvennykh issledovaniy, k 100-letiyu otkrytiya uslovnogo refleksa) [Salivary glands and saliva as sensitive objects of research on the body's stress resistance (Review of our own research, to the 100th anniversary of the discovery of the conditioned reflex]. Ukrainskyi stomatolo- 
Огляди літератури, оригінальні дослідження, погляд на проблему, випадок з практики, короткі повідомлення hichnyi almanakh - Ukrainian Dental Almanac, 5-6, 31-34 [in Russian].

6. Yerichev, I.V., Korotko, G.F., \& Skorikova, L.A. (2004). Lateralizirovannost salivatsii u lyudey s intaktnymy zubnymi ryadami [Salivation lateralization in people with intact dentition]. Allergologiya i immunologiya - Allergology and Immunology, 5 (3), 520 [in Russian].

7. Mimura, M., Tanaka, N., \& Ichinose, S. (2005). Possible etiology of calculi formation in salivary glands: biophysical analysis of calculus. Med. Mol. Morphol, 38 (3), 189-195.

8. Kajikawa, S., Takeuchi, A., \& Nii A. (2005). Temporal reduction in size of salivary acinus in rats induced by theophylline. Toxicol. Pathol, 33 (2), 218-224.

9. Gilon, Y. (2006). Systemic pathology and the salivary glands. Rev. Blge. Med. Dent., 61 (3), 154-160.

10. Hnatyuk, M.S., Tatarchuk, L.V., \& Slabyy, O.B. (2019). Osoblyvosti strukturnoi perebudovy kardiomio-

tsytiv peredserd $v$ umovakh postrezektsiinoi lehenevoi hipertenzii [Features of structural rearrangement of atrial cardiomyocytes in the conditions of postresection pulmonary hypertension]. Visnyk problem biolohii i medytsyny Bulletin of Problems of Biology and Medicine, 3, 283-286 [in Ukrainian].

11. Frasch, H., Marshall, C., \& Marshall, B. (2002). Endothelin-1 is elevated in monocrotalin pulmonary. Am. J. Physiol., 300 (2), 442-449.

12. Hnatyuk, M.S., Tatarchuk, L.V., \& Slabyy, O.B. (2016). Osoblyvosti remodeliuvannia kamer sertsia z riznymy typamy krovopostachannia pry arterialnii hipertenzii v malomu koli krovoobihu [Features of remodeling of chambers of heart with different types of blood supply at arterial hypertension in a small circle of blood circulation]. Visnyk problem biolohiyi i medytsyny - Bulletin of Problems of Biology and Medicine, 3 (3), 41-45 [in Ukrainian].

\title{
МОРФОМЕТРИЧНЕ ВИВЧЕННЯ АСПЕКТІВ РЕОРГАНІЗАЦІї АРТЕРІЙ ПІДНИЖНЬОЩЕЛЕПНОЇ ЗАЛОЗИ ПРИ ЗМОДЕЛЬОВАНІЙ ПОСТРЕЗЕКЦІЙНІЙ АРТЕРІАЛЬНІЙ ЛЕГЕНЕВІЙ ГІПЕРТЕНЗІї
}

\section{๑л. я. Посоленик}

\author{
Тернопільський національний медичний університет імені І. Я. Горбачевського мОз України
}

РЕЗЮМЕ. Слинні залози $є$ особливою групою секреторних органів, які відіграють значну роль у стоматологічному здоров'ї населення, а також життєдіяльності цілого організму людини. 3 розвитком сучасної медичної науки клініцисти стали часто діагностувати патологію слинних залоз. Серед важливих проблем виникнення цих патологій $\epsilon$ вивчення прямих і зворотних впливів органів один на одного, принципів їх кореляцій та способів морфологічного вираження. За останні десятиліття також відмічено збільшення випадків уражень легень, які супроводжуються гіпертензією в малому колі кровообігу і призводять до розвитку легеневого серця та його декомпенсації. Існують поодинокі дослідження, присвячені особливостям втягнення піднижньощелепної залози у патологічний процес, і лише деякі роботи відображають структурні зміни підщелепної залози при гемодинамічних порушеннях.

Мета - морфометричне вивчення аспектів реорганізації артерій піднижньощелепної залози при змодельованій пострезекційній артеріальній легеневій гіпертензії.

Матеріал і методи. Комплексом гістологічних та морфометричних методів досліджені артерії середнього (51-125 мкм) та дрібного (26-50 мкм) калібрів піднижньощелепної слинної залози 27 свиней в'єтнамської породи, які були поділені на 3 групи. 1-а група включала 9 інтактних тварин віком 6,5-7 міс., 2-а - 12 свиней аналогічного віку з пострезекційною легеневою гіпертензією і компенсованим легеневим серцем, 3-я - 6 тварин 6,5-7 міс. 3 легеневою гіпертензією і декомпенсованим легеневим серцем.

Результати. Одномісячна гіпертензія у малому колі кровообігу, яка виникала після правосторонньої пульмонектомії, призводила до розвитку легеневого серця і венозного застою в органах великого кола кровообігу, в тому числі у піднижньощелепній залозі. При артеріальній гіпертензії у малому колі кровообігу виявлена суттєва структурна перебудова артерій піднижньощелепної залози. Більш виражені морфологічні зміни виявлені у артеріях дрібного калібру досліджуваного органа та при декомпенсації легеневого серця.

Висновки. Проведене комплексне морфологічне дослідження дозволило отримати всесторонню інформацію про особливості ремоделювання артерій піднижньощелепної залози при пострезекційній артеріальній легеневій гіпертензії. Тривала легенева гіпертензія призводить до вираженої структурної перебудови артерій середнього та дрібного калібрів піднижньощелепної залози, яка характеризується потовщенням стінок, звуженням їх просвіту та ушкодженням ендотеліоцитів, погіршанням кровопостачання та розвитком гіпоксії в органі. Найвираженіше змінюються артерії дрібного калібру піднижньощелепної залози та при декомпенсації легеневого серця у 6,5-7-місячних свиней-самців в'єтнамської породи.

КлючОВІ СлОВА: піднижньощелепна залоза; артерії; ремоделювання; легенева гіпертензія. 
Огляди літератури, оригінальні дослідження, погляд на проблему, випадок з практики, короткі повідомлення

\title{
МОРФОМЕТРИЧЕСКОЕ ИЗУЧЕНИЕ АСПЕКТОВ РЕОРГАНИЗАЦИИ АРТЕРИЙ ПОДНИЖНЕЧЕЛЮСТНОЙ ЖЕЛЕЗЫ ПРИ СМОДЕЛИРОВАННОЙ ПОСТРЕЗЕКЦИОННОЙ АРТЕРИАЛЬНОЙ ЛЕГОЧНОЙ ГИПЕРТЕНЗИИ
}

๑л. я. Посоленик

\author{
Тернопольский национальный медицинский университет имени И. Я. Горбачевского МОз Украины
}

РЕзюМЕ. Слюнные железы представляют собой особую группу секреторных органов, которые играют значительную роль в стоматологическом здоровье населения, а также жизнедеятельности целого организма человека. С развитием современной медицинской науки клиницисты стали часто диагностировать патологию слюнных желез. Одной из важных проблем возникновения данных патологий является изучение прямых и обратных воздействий органов друг на друга, принципов их корреляций и способов морфологического выражения. За последние десятилетия также отмечено увеличение случаев поражений легких, сопровождающихся гипертензией в малом круге кровообращения, что приводит к развитию легочного сердца и его декомпенсации. Существуют единичные исследования, посвященные особенностям вовлечения поднижнечелюстной железы в патологический процесс, и только некоторые работы отражают структурные изменения подчелюстной железы при гемодинамических нарушениях.

Цель - морфометрическое изучение аспектов реорганизации артерий поднижнечелюстной железы при смоделированной пострезекционной артериальной легочной гипертензии.

Материал и методы. Комплексом гистологических и морфометрических методов исследованы артерии среднего (51-125 мкм) и мелкого (26-50 мкм) калибров поднижнечелюстной слюнной железы 27 свиней вьетнамской породы, которые были поделены на 3 группы. Первая группа включала 9 интактных животных возрастом 6,5-7 мес., вторая - 12 свиней аналогичного возраста с пострезекционной легочной гипертензией и компенсированным легочным сердцем, третья- 6 животных 6,5-7 мес. с легочной гипертензией и декомпенсированным легочным сердцем.

Результаты. Одномесячная гипертензия в малом круге кровообращения, которая возникала после правосторонней пульмонэктомии, приводила к развитию легочного сердца и венозного застоя в органах большого круга кровообращения, в том числе в поднижнечелюстной железе. При артериальной гипертензии в малом круге кровообращения обнаружена существенная структурная перестройка артерий поднижнечелюстной железы. Более выраженные морфологические изменения выявлены в артериях мелкого калибра исследуемого органа и при декомпенсации легочного сердца.

Выводы. Проведенное комплексное морфологическое исследование позволило получить всестороннюю информацию об особенностях ремоделирования артерий поднижнечелюстной железы при пострезекционной артериальной легочной гипертензии. Длительная легочная гипертензия приводит к выраженной структурной перестройке артерий среднего и мелкого калибров поднижнечелюстной железы, которая характеризуется утолщением стенки, сужением их просвета и повреждением эндотелиоцитов, ухудшением кровоснабжения и развитием гипоксии в органе. Наиболее выраженно меняются артерии мелкого калибра поднижнечелюстной железы и при декомпенсации легочного сердца у 6,5-7-месячных свиней-самцов вьетнамской породы.

КЛЮчЕВЫЕ СЛОВА: поднижнечелюстная железа; артерии; ремоделирование; легочная гипертензия.

Отримано 12.10.2020 